\title{
EDITORIAL ARTICLES.
}

\section{IMMUNITY AGANST TEYANLS.}

THE greatest possibilities, and the most hopeful outlook in therapeutics. seem to lie along the line of the employment of bacterial products as antidotes to these very products in some different form ; and it is to bacterial products that we are now looking for the remedies with which to overcome the great category of infections diseases.

Through the researches of Beluring it was found that it is possible to render animals immune to tetanus by inoculations with the bloodserun of animals which had been rendered immune by treatment with tetanus products; and that it is also possible to cure animals by. this means eren when they are suffering from the disease.

Behring has olsserved that, unlike vaccination, in which a very small amount of the serum is sufficient, the tetamns serum must be given in a definite and fixed amount in proportion to the weight of the animal to be treated. His original experiments carried out on mice and rabbits gave no adequate idea as to the amount of the remedy which should be used in man; and he found it necessary to experiment on sheep and animals which had a body weight nearer to that of man. The more intensely the animal was inoculated to render it immune, and the longer it had remained inoculated, just so much less of its serum was required to cause immunity in another animal. For example, one gramme of serum from an animal which had been immune for a few weeks would protect an animal weighing I 00 grammes; whereas, after the lapse of many weeks or months, the immune animal would supply a sermm of which one gramme would save an infected animal weighing 500 or 1000 grammes. After the course of one year he had worked the thing down to such a fine point 
that a horse, upon which he experimented, supplied a serum which had an immunizing value of $I: I, 000,000$,-that is, a serum of which one gramme sufficed to render immune 1000 animals, each weighing rooo grammes. This small dose refers to the amount required to cause immunity in a well animal. When used in a therapentic sense to check a tetanus which has already broken ont, a much larger amount is given, -at least a thousand times this amount. Therefore a serum with an immunizing value of $1: 1,000,000$ possesses a therapentic value of $I$ : 1000 .

Rotter $^{\prime}$ reports the case of a hostler, a muscular young man, who received a wound from an iron hook, tearing the fold between the thumb and index finger. Within fifteen minutes the wound had been irrigated with carbolic solution, and sutured by a surgeon in the neighborhood, and at the end of a week was perfectly healed. Eight days after the accident the patient observed a certain stiffness of the fingers, and opening and closing the hand was with some difficulty. In this condition he contiuted to work three more days. Two weeks after the injury, trismus, difficulty in swallowing, and pain in the neck developed. His general condition was so disturbed that he had to go to bed. On the following day trismus was pronounced, swallowing was very difficult, and the muscles of the back were lsecoming contracted. These symproms grew more pronounced. The wound-scar was dense and seusitive, and formed a ridge the thickness of a leadpencil. The hand was perfectly stiff, and the muscles of the arm were firmly contracted. The mouth would just admit the little finger, but in talking the teeth were tightly closed. The muscles of the face were contracted, and the back and belly were firm and hard. Occasionally convulsions were olserved. Opisthotonos was so marked as to allow the passage of the fist between the back and the bed. On attempting to set the patient up, the whole trumk seemed one solid, inflexible mass. The legs were but slightly affected. Urination was difficult. The urine contained albumen. Perspiration was profuse. Temperature and pulse-rate

' Rotter: Deutsche nuedicinische Wochenschrift, No. 7, 1893, p. 152. 
during the whole disease were normal. This was the condition of the patient when bronght to the clinic. On the following day the patient was more depressed, the muscular rigidity had extended to the legs. The jaws conld not be separated more than one centimetre, and the head, neck, and trunk were as stiff as a piece of wood. The introduction of a needle into the left arm caused a convulsion of the whole left sicle. The scar in the hand was excised, and found to contain small particles of dirt. On the same day the patient was injected in the back with sixty-six grammes of blood-serum from an immunized horse, to this being added 5 per cent. carbolic acid. The only narcotic given during the clisease was .or gramme of morphine. On the day following the injection, convulsions occurred as before. A second injection of fifty grammes was made in the pectoralis major with fresh serum, having an immunizing strength of $I$ : I, $, 00,000$. Next day the patient declared that he felt better. The muscular contractions persisted, bit there were no further convulsions. Forty-five grammes of the same serum were injected on the following day, and the muscles of the face and back were much less rigid. On the fifth day of daily injections a final dose of fifty cubic centimetres of sermu was injected.

The improvement continued till the patient was up and about; on the nintl day after treatment was discontinued. On the serenteenth day he left the clinic, and by the twenty-second all rigidity of the affected hand and forearm had disappeared.

Although a very large amount of the blood-serum had been used (250 grammes), no sign of harmful effect hat been olsserved. The first two injections were accompanied with pain. but after this the treatment was quite painless. The tissnes very quickly took up the large doses. Fifty grammes in one mass, under gentle massage, would be absorbed in a few hours, without cansing any irritation to the tissues. The 0.5 per cent. of carbolic acid was added in each case.

Before estimating the value of the treatment in this case, the question of prognosis must first be considered. Here was a case of 
tetanus in which the first symptoms of muscular spasm in the affected arm had developed eight days after the infection. On the fifteenth day lock-jaw wits present ; on the sixteenth, there developed spasm of the muscles of the abdomen and back; on the eighteenth, the spasmodic contractions involved the leg muscles; and until the twenty-seccond day, on which the treatment was begun, all of these symptoms were steadily growing worse. The treatment was begun after the symptoms had continued fourteen days. From that time, after two days of no observalule change, the symptoms steadily abated.

Ricluter, ${ }^{1}$ in his statistics, shows that in ninety-one cases, in which the period of incubation was as short as six to ten days, but 4.4 per cent. of the cases recovered. So that the chances of this patient of Rotter's recovering were very small indeed. And it appears very probable that the treatment at least influenced the course of the discase.

Similar experiences to the alove have been reported by 'Tizzoni," thongh his cases were less acute than the one described above.

An interesting study of the sulbject of tetanus has been made by Buschke and Oergel in the surgical clinic at Greifswald." I nineyear-old boy was admitted to the clinic with the history of having been kicked ly a horse on the previons day. He had sustained a compound fracture of the leg. Things progressed well until the morning of the eighth day, when he developed trismus and opisthotonos. In the course of the morning the symptoms of tetanus became more and more pronounced as successive gromps of muscles were involved. At eleven o'clock the dressings were changed under an anasthetic. At six o'clock, under narcosis, sixty cubic centimetres of blood were drawn from the right median vein for purposes of examination. At nine o'clock the tenesmus was very pronounced, and he

'Allgemeine Chirurgie der Schussverletzungen im Kriege, $18_{77}$, S. $S_{45}$.

2 Tizzoni-Caltani : Riforma medica, 1892, 11, p. 5.

3 Beilrag zur Kentniss der Telanus, Deulsche medicinische Woclienschrift, No. 7 , IS9j. 
was given an injection of ten cubic centimetres of Behring's sermm subcutaneonsly. Half an hour later the lad died. The autopsy showed no sign of phlegmonous infiltration of the soft parts aloont the fracture.

This case was made the starting-point of a series of investigations. Some of the granulation naterial from the stat of fracture was employed to inocnlate two mice, which developed the characteristic symptoms of tetanus on the second day and clied. The pus from the wounds in these mice was used to inocnlate two other mice. Both died of tetauns at the end of ten and fourteen hours res]ectively. Cultures were made from the pus at the inoculation wounds; and mice treated with these pure cultures died of tetanus.

The blood which had been alstracted from the patient was found to be sterile, it giving rise to no growth when applied to agar. It was allowed to stand on ice for twenty-four hours, and the supernatant sermm wis employed in the following experiments:

A gninea-pig was injected with one culric centimetre of this fluid. Another guinea-pig was inoculated lyy placing a small cylincler of the coagulmm beneath the skin and closing the wound. 'lhe first pig died on the sixth day, and the second died on the tenth day after the operation. Eiach siffered from opisthotonos and the other symptoms of tetanus.

This blood, it will be remembered, had been drawn before the patient was inoculated with lehring's serum. loor further experimentation, blood was taken from the inferior vena cava of the corpse, and the sermm of this blood sejarated. This also was found to be sterile. A guinea-pig was injected with one cubic centimetre of this sermm; a monse was given 0.5 cnbic centimetre; and another monse was treated with a bit of the clot beneath the skin. This last monse developed conwulsions soon after the operation ; lut after a few hours it recovered and remained perfectly well. Alsolutely no simptoms were olsserved in the other two animals. Is a resnlt of these ulservations it must be concluded that the injection of ten culbic centimetres of Behring's sermm had had an antitoxic effect. 
Experiments with the saliva and sweat gave negative results.

From the liver, spleen, and spinal cord of animals perishing from tetanus, Buschke has been able to isolate an albuminoid material, which causes rapid and fatal tetanus in small animals.

It is worthy of note that in all of these animals free fat particles were found in the blood, and the question arises as to whether these may not play a róle in the causing of death.

Buschke has also carried ont a series of experiments to decide upon what organs the tetanus poison acts, - whether upon the nuscles directly or on the peripheral nerves, or upon the nerve-centres. $\mathrm{He}$ experimented upon frogs with a very virulent culture of tetanus bacilli on bouillon. Ten frogs were inoculated and kept at room temperature. At the end of two weeks four of the frogs had developed tetanus. One of these was treated with curara. The tetanus immediately suls. sided and the animal died after an hour.

The sciatic nerve of another frog was cut out. Before the operation, the extremity had been the seat of rigid spasmodic contraction following the slightest touch. After dividing the nerve the leg humg loosely, and but slight convulsive movements could be excited. This frog was then poisoned with curara, and the tetanus at once subsided.

A third frog was decapitated, and the tetanic symptoms continued.

A narrow needle was passed into the lower part of the cord of another frog. As a result of this destroying the spinal cord, the tetanic symptoms disappeared from the lower limbs.

'These experiments tend to show that the tetanus poison does not act directly upon the muscles, nor upon the peripheral motor-nerves, nor upon the brain, but that the spinal cord is the organ chiefly affected.

JAMES P. WARIBASSE. 